\title{
Eucalyptus pellita Actived Carbon for Fe Absorption Effect of Carbonization Temperature and Concentration of $\mathrm{KOH}$ Activator
}

\author{
Leila Kalsum ${ }^{1 *}$, Idha Silviyati ${ }^{1}$ Jenie Fahlevi Putri ${ }^{1}$ \\ ${ }^{1}$ Department of Chemical Engineering, Sriwijaya State Polytechnic, Bukit Besar, Palembang 30139, Indonesia \\ *Corresponding author. Email: leila_k@polsri.ac.id
}

\begin{abstract}
Eucalyptus pellita bark is a waste from the pulp industry that can be used as a raw material in activated carbon manufacturing because it contains high enough cellulose, hemicellulose, and lignin. This study aims to determine the effect of various carbonization temperatures and $\mathrm{KOH}$ activator concentrations on $\mathrm{Fe}$ absorption in water. Making activated carbon procedure consisted of dehydration, carbonization, and activation. Furthermore, the analysis of activated carbon characteristics was based on Fe absorption. The variations of this study consisted of carbonization temperature, $250^{\circ} \mathrm{C}, 300^{\circ} \mathrm{C}$, and $400^{\circ} \mathrm{C}$, and variations of $\mathrm{KOH}$ activator concentrations, $0.2 \mathrm{~N}, 0.7 \mathrm{~N}$, and $1.2 \mathrm{~N}$. The best-Eucalyptus pellita bark activated carbon obtained for carbonization temperature at $350^{\circ} \mathrm{C}$ and an activator concentration at $1.2 \mathrm{~N}$ with the value of $\mathrm{Fe}^{2+}$ absorption was $95.343 \%$.
\end{abstract}

Keywords: Activated carbon, Eucalyptus pellita bark, adsorption, potassium hydroxide.

\section{INTRODUCTION}

Like other chemical elements, heavy metal elements are also needed by living organisms in various metabolic processes for the growth and development of body cells. For example, iron $(\mathrm{Fe})$ is needed for the manufacture of hemoglobin. But heavy metal elements in excessive amounts will be toxic [1]. Toxicity of heavy metals depends on the type, concentration, synergistic-antagonist effect and physic-chemical form. The greater the heavy metal content, the greater the toxicity [2].

The presence of dissolved iron in water causes the water to become red, yellowish, smells fishy and forms an oil layer [3]. Drinking water with high iron content can cause nausea when consumed and is very dangerous for health, so it is necessary to reduce iron levels in the water. One method that can be used to reduce the iron content in water is the adsorption method. The process of mass transfer on the surface of the pores on the adsorbent granules is known as adsorption. Liquid-solid and gas-solid are the boundary between two phases that mass transfer occurs [4]. A solid material with a very large internal surface area is called an adsorbent. This large surface is formed due to the many fine pores in the solid [4]. One of the adsorbents known to many people is activated carbon.

Activated carbon is very good at absorbing harmful substances in water. In Indonesia, the need for activated carbon in the industrial sector is still relatively high due to being widely used in the industrial sector [5]. Activated carbon is charcoal with a microcrystalline or amorphous structure that mostly consists of free carbon, and has an internal surface, with a surface area ranging in 300-2000 $\mathrm{m}^{2} / \mathrm{gr}$ [6]. Activated carbon can be used in filters, which absorb odors, reduce water color intensity, absorb odors, and absorb metals [7]. Activated carbon is usually produced from natural materials containing lignocellulose, namely cellulose, lignin, and hemicellulose. [8]. Judging from the abundant natural resources in Indonesia, it is very possible that the need for activated carbon can be met from domestic production [9]. One of the natural ingredients is eucalyptus pellita bark waste produced by the pulp and paper industry. 
The methods used in this research have followed some steps, namely bark dehydration, carbonization, and chemical activation. The dehydration process occurs using an oven at $100^{\circ} \mathrm{C}$ for heating until obtaining a constant weight. Dehydration aims to acquire dry and pure material and facilitate the carbonization process. The process of carbonization or composing was carried out by heating the raw materials using a furnace. Carbonation (combustion) is an incomplete pyrolysis (burning) process with limited air from carboncontaining materials. In this process the formation of the pore structure began. This process aimed to produce granules that have absorbancy and a neat structure. In the carbonation process there was shrinkage of the sample. It was because the heating given during the carbonation process removed the particles contained in the sample so that only palm frond charcoals remain [10]. The activation process is a process that breaks hydrocarbon bonds or oxidizes surface molecules so that the charcoal changes properties, both chemical and physical, that is a treatment of charcoal that aims to enlarge the pores, the surface area increases and affects the adsorption power [11].

In this study, carbonization was carried out at various temperatures of $300^{\circ} \mathrm{C}, 350^{\circ} \mathrm{C}$ and $400^{\circ} \mathrm{C}$. The solid material left after carbonization was carbon in the form of charcoal with narrow pores. Furthermore, the carbon was activated chemically by using various activators of KOH $0.2 \mathrm{~N}, 0.7 \mathrm{~N}$ and $1.2 \mathrm{~N}$. KOH is a good activator to expand the surface of the adsorbent. So it increases the absorption of harmful substances. This study aimed to analyze the effect of carbonization temperature and $\mathrm{KOH}$ activator concentration on the absorption of iron metal in water.

\section{RESEARCH METHOD}

This research method is divided into three parts, namely materials and tools, research procedures, and $\mathrm{Fe} 2+$ absorption analysis.

\subsection{Materials and Instruments}

The material used in this study was Eucalyptus pellita bark waste obtained from PT. Tanjungenim Lestari Pulp and Paper in Empat Petulai Dangku District, Muara Enim Regency. Other materials used include Aquades, $\mathrm{KOH} 0.2 \mathrm{~N}, 0.7 \mathrm{~N}$ and $1.2 \mathrm{~N}, \mathrm{HCl} 0.1$ M. Other materials and instruments used including analytical balance, 70 mesh sieve, filter paper, oven, furnace, desiccator, Porcelain cup, Crucible cup, Stirrer,
$250 \mathrm{ml}$ and $500 \mathrm{ml}$ beakers, Volumetric flask, Measuring cup, Spatula , and Watch glass

\subsection{Research procedure}

\subsubsection{Activated Carbon Production}

1. Samples were dried using an oven at a temperature of $110^{\circ} \mathrm{C}$.

2. Raw materials were carbonized for 30 minutes using a furnace (there were variations in carbonization temperature, namely $300^{\circ} \mathrm{C}, 350^{\circ} \mathrm{C}$ and $400^{\circ} \mathrm{C}$

3. The raw materials were grinded using a grinder and sieved with a 70 mesh sieve shaker.

4. 20 grams of raw materials were mixed into $100 \mathrm{ml}$ of activator solution (there were variations in the type of activator, namely KOH $0.2 \mathrm{~N}, 0.7 \mathrm{~N}$ and 1.2 $\mathrm{N}$. This activation process was carried out for 24 hours.

5. Activated carbon was washed with distilled water and filtered to obtain a $\mathrm{pH}$ of 7 .

6. Activated carbon which had been neutral then dried for 1 hour using an oven at a temperature of $110^{\circ} \mathrm{C}$.

\subsubsection{The Analysis of $\mathrm{Fe}^{2+}$ Absorption Testing by Eucalyptus Pellita Bark Activated Carbon}

1 gram of activated carbon was weighed and mixed with $100 \mathrm{ml}$ of $20 \mathrm{ppm}$ Fe solution. The sample was then stirred for 60 minutes using a stirrer. The mixture was then filtered using filter paper to take the filtrate. The filtrate was then tested for iron content using Atomic Absorption Spectrophotometer (AAS), namely the SNI method 06-6989.4-2004 [12] in the Laboratory of Analytical Chemistry Instruments. The concentration of Fe metal that was absorbed by activated carbon that calculated by the equation:

Absorbed Fe Metal Level $=\frac{C 1-C 2}{C 1} \times 100 \%$

Annotation:

$\mathrm{C} 1$ = Initial concentration of solution $(\mathrm{ppm})$

$\mathrm{C} 2$ = Solution concentration after contact with activated carbon (ppm)

\section{RESULTS AND DISCUSSION}

Determination of the absorption of iron aims to determine the performance of activated carbon against harmful metals such as iron. The method used was the light of atom absorption. Depending on the nature of the elements, the atoms absorb the light at specific wavelengths. To determine the sample density (ppm) 
compared to the peak height of the sample and the standard.

\subsection{The Effect of $\mathrm{KOH}$ Activator Concentration and Carbonization Temperature on the Absorption of Iron (Fe) in Water}

The effect of $\mathrm{KOH}$ activator concentration and carbonization temperature on iron absorption can be seen in Figures 1 and 2 as follows.

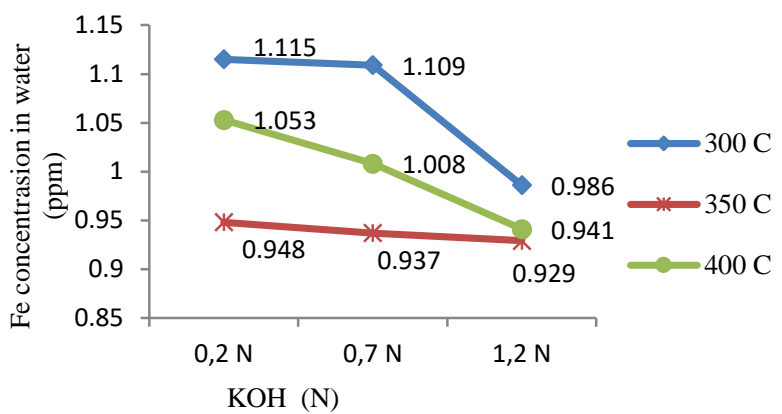

Figure 1 The Effect of $\mathrm{KOH}$ Activator Concentration and Carbonization Temperature on the Decrease of $\mathrm{Fe}$ Concentration in Water

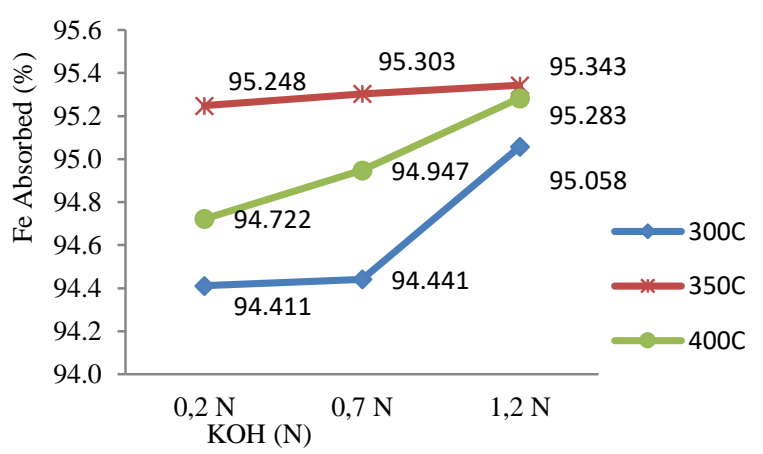

Figure2 The Effect of $\mathrm{KOH}$ Activator Concentration and Carbonization Temperature on Absorption of $\mathrm{Fe}$ Content.

Based on the absorption data, carbonization temperature at $350^{\circ} \mathrm{C}$ and the highest $\mathrm{KOH}$ activator concentration at $1.2 \mathrm{~N}$ was the optimum condition to absorb Fe by activated carbon with $95.34 \%$. It is in line with research conducted by [13] which states that the greater the concentration of $\mathrm{KOH}$, the greater the degradation of the material occurs so that the yield value will decrease.

However, the difference in the absorption of Fe, both variations in carbonization temperature and activator concentration, was not very significant. All samples had good absorption, which was greater than 90\%. The contact time of each sample for 2 hours and stirring at $100 \mathrm{rpm}$ for 1 hour was very influential to produce good adsorbent absorption.
From the results of the study, the concentration of $\mathrm{Fe}$ metal decreased along with the increase in the concentration of $\mathrm{KOH}$ activator. It was because the concentration of the activator was one of the factors that affected the absorption by the adsorbent. The higher of activator concentration, the activated carbon pores are open larger and affected to increase the activated carbon absorption capacity and increase the activated carbon surface area. The existence of $\mathrm{KOH}$ as an activating agent kept the sample from burning by reacting with the mineral content in the raw material so that no ash was formed and caused a grayish color [14].

The activation process was also resulting in the loss of carbon because it formed carbon dioxide gas. The chemical reactions occurred in the manufacture of activated carbon with $\mathrm{KOH}$ activator following equations 2), 3), and 4):

$\mathrm{C}+6 \mathrm{KOH} \leftrightarrow 2 \mathrm{H}_{2} \mathrm{O}+4 \mathrm{~K}+\mathrm{CO}_{2}$
$\mathrm{C}+6 \mathrm{KOH} \leftrightarrow 2 \mathrm{~K}+2 \mathrm{~K}_{2} \mathrm{CO}_{3}+3 \mathrm{H}_{2}$
$2 \mathrm{CO}_{2}+4 \mathrm{KOH} \leftrightarrow 2 \mathrm{H}_{2} \mathrm{O}+2 \mathrm{~K}_{2} \mathrm{CO}_{3}$

The above reaction also released water because $\mathrm{KOH}$ is a dehydrating agent. In this activation process the carbon reacted with $\mathrm{KOH}$ so that the carbon was eroded (forming carbon dioxide) resulting in the formation of pores. The formation of these pores enlarged the activated carbon surface area obtained and the adsorption efficiency also increased [13].

The temperature effect in the activated carbon absorption is closely related to the formation of carbon pores [15]. When the carbonization is in process, CO2 gas is released and forms a certain size of pores that become an absorption surface area unit, where the larger absorption surface area affected the higher activated carbon absorption as a result.

In the carbonization process, the adsorption was still relatively low, but the surface area was exposed but. It is caused by tar residue that covers the pores. Tar will dissolve when soaked in chemical activation [16]. [17] Stating that in the activation process, chemical solution mixed with a chemical solution and oxidation will occur and it damages the interior of the carbon, as a result, the number of pores becomes larger. The activation process also results in the loss of carbon because it forms carbon dioxide gas

From the research conducted, the best activated carbon was found at the carbonization temperature of $350^{\circ} \mathrm{C}$ and the activation concentration of $1.2 \mathrm{~N}$ with the absorption of Fe, which is $95.343 \%$. 


\section{CONCLUSION}

Based on the results of the research conducted, it can be concluded that this study obtained activated carbon from Eucalyptus pellita bark regarding Indonesian National standards. The higher the carbonization temperature, the larger the activated carbon pores surface, and high temperatures caused the carbon to become brittle. So it needs a suitable temperature for the activated carbon from Eucalyptus pellita bark manufacturing, which was $350^{\circ} \mathrm{C}$. The higher of the $\mathrm{KOH}$ activator concentration affected to the better quality of the activated carbon. The optimum concentration of the activator was $1.2 \mathrm{~N}$, for the absorbed Fe content was $95.355 \%$.

\section{AUTHORS' CONTRIBUTIONS}

All autors in this publication have jointly carried out research activities and writing this article.

\section{ACKNOWLEDGMENTS}

This article's research/publication sponsored from DIPA Politeknik Negeri Sriwijaya 2021. We gratefully thank to Director and Research Unit and Community of Politeknik Negeri Sriwijaya for their strong support of this study.

\section{REFERENCES}

[1] Phillips DJ, Proposal for monitoring studies on the concentration of the East Asian Seas by trace metals and organochlorines. Dalam" South Chine fisheries development and coordinating programme. FAO. Manila. 1980, pp. 7.

[2] Hutagalung HP, Logam berat dalam lingkungan laut. Pewarta Oceana IX. 1984;1, pp. 45-59.

[3] Joko, T, Unit Produksi dalam Sistem Penyediaan Air Minum, Yogyakarta: graha ilmu, 2010.

[4] Asip F, Mardhiah R, Husna H, Uji efektifitas cangkang telur dalam mengadsorbsi ion $\mathrm{Fe}$ dengan proses batch, vol. 15, Jurnal Teknik Kimia, 2008. pp. 22-26.

[5] Zulfadhli M, Pembuatan Karbon Aktif Dari Cangkang Buah Karet (Hevea Brasilliensis) dengan Aktivator $\mathrm{H}_{3} \mathrm{PO}_{4}$ dan Aplikasinya Sebagai Penjerap Cr (VI). Vol. 6, No.1, Jurnal Teknik Kimia USU, 2017, pp. 23-8.

[6] Ramdja AF, Halim M, Handi J. Pembuatan karbon aktif dari pelepah kelapa (Cocus nucifera), vol. 15, no. 2, Jurnal Teknik Kimia, 2008, pp. 1-8.
[7] Noer, A.A., Awitdrus, Malik, U., Pembuatan Karbon Aktif dari Pelepah Kelapa Sawit Menggunakan Aktivator $\mathrm{H}_{2} \mathrm{O}$ sebagai Adsorben, vol. 1, no. 2, Jom FMIPA, 2014, 42-47.

[8] Harini R, Farma R, Pengaruh Persentase Kalium Hidroksida Terhadap Sifat Fisis Karbon Aktif Kayu Eucalyptus Pellita, Jurnal Teknik Kimia. Pekan Baru: Universitas Riau, 2017, pp. 1-9.

[9] Haryati S, Yulhan AT, Asparia L, Pembuatan Karbon Aktif dari Kulit Kayu Gelam (Melaleuca Leucadendron) yang Berasal dari Tanjung ApiApi Sumatera Selatan, vol. 23, no. 2, Jurnal Teknik Kimia, 2017, pp. 77-86.

[10] Masthura, Peningkatan Daya Serap Filter Air Dari Karbon Aktif Tempurung Kelapa Dengan Memvariasikan Suhu Pemanasan, Tesis FMIPA USU, 100100075, 2013, pp. 246-247.

[11] Hartanto S, Ratnawati R. Pembuatan Karbon Aktif Dari Tempurung Kelapa Sawit Dengan Metode Aktivasi Kimia, vol. 12, no. 1, Jurnal Sains Materi Indonesia, 2010, pp. 12-6.

[12] Nasional-bsn, B. S, SNI 06-6989.4-2004. Surabaya: Badan Standardisasi Nasional-bsn, 2004.

[13] Erlina E, Umiatin U, Budi E, Pengaruh konsentrasi larutan $\mathrm{KOH}$ pada karbon aktif tempurung kelapa untuk adsorpsi logam $\mathrm{Cu}$, vol. 4, InProsiding Seminar Nasional Fisika (E-Journal), 2015, pp. 55-59.

[14] Hessler. J.W, Active Carbon, Chemical Publishing Co Inc R, New York, 1951.

[15] Rohmah PM, Redjeki AS, Pengaruh waktu karbonisasi pada pembuatan karbon aktif berbahan baku sekam padi dengan aktivator $\mathrm{KOH}$, vol.3 no.1, Jurnal Konversi, 2014, pp. 19-27.

[16] Pambayun GS, Yulianto RY, Rachimoellah M, Putri EM, Pembuatan karbon aktif dari arang tempurung kelapa dengan aktivator $\mathrm{ZnCl} 2$ dan $\mathrm{Na}_{2} \mathrm{CO}_{3}$ sebagai adsorben untuk mengurangi kadar fenol dalam air limbah, vol.2 no.1, Jurnal Teknik ITS, 2013.

[17] Melania MS, Produksi Karbon Aktif dari Bambu dengan Aktivasi menggunakan Kalium Hidroksida. Skripsi. Departemen Teknik Kimia, Fakultas Teknik, Universitas Indonesia, 2012. 